\title{
Identification and Characterization of Drosophila Genes for Synaptic Vesicle Proteins
}

\author{
Aaron DiAntonio,' Robert W. Burgess, ${ }^{1}$ Allison C. Chin, ${ }^{1,2}$ David L. Deitcher, ${ }^{1}$ Richard H. Scheller, ${ }^{1,2}$ and \\ Thomas L. Schwarz' \\ 'Department of Molecular and Cellular Physiology and ${ }^{2}$ Howard Hughes Medical Institute, Stanford University Medical \\ Center, Stanford, California 94305-5426
}

Proteins associated with synaptic vesicles are likely to control the release of neurotransmitter. Because synaptic transmission is fundamentally similar between vertebrates and invertebrates, vesicle proteins from vertebrates that are important for synaptic transmission should be present in Drosophila as well. This investigation describes Drosophila homologs of vamp, synaptotagmin, and rab3 that are expressed in a pattern consistent with a function in Drosophila neurotransmission. One previously reported candidate (syb), a Drosophila homolog of the vamp or synaptobrevin proteins, has been shown to be expressed at very low levels in neurons and is most abundant in the gut. A neuronal Drosophila vamp $(n-s y b)$ is described here and is localized to chromosome band 62A. Northern analysis and in situ hybridizations to mRNA indicate that the novel vamp, as well as the genes for synaptotagmin (syt) and rab3 (drab3), is expressed in the Drosophila nervous system. These genes are widely (perhaps ubiquitously) expressed in the nervous system and we have no evidence of additional neuronal isoforms of synaptotagmin, vamp, or rab3. Immunoreactivity for synaptotagmin and vamp is located in synaptic regions of the nervous system. This distribution suggests that these molecules are components of synaptic vesicles in Drosophila. The conserved structure and neuronal expression pattern of these genes indicate that they may function in processes that are required for both vertebrate and invertebrate synaptic transmission. Because of their distribution in the nervous system and because $n$-syb, synaptotagmin, and $d r a b 3$ do not appear to be in a family of functionally redundant homologs, we predict that mutation of these genes will have a profound neurological phenotype and that they are therefore good candidates for a genetic dissection in Drosophila.

[Key words: synaptic vesicles, Drosophila, vamp, synaptobrevin, synaptotagmin, p65, rab3]

\footnotetext{
Received Dec. 4, 1992; revised Apr. 26, 1993; accepted May 27, 1993.

A.D. and R.W.B. contributed equally to this article. We are grateful to B. Baker, L. Elferink, L. Green, L. Hinck, K. Miller, and B. Wendland for assistance and reagents and to $I$. Inman for outstanding technical assistance. This work was supported by the McKnight Foundation (T.L.S.) and a Silvio Conti Center for Neuroscience Award from the NIMH (T.L.S. and R.H.S.). A.D. was supported by an MSTP fellowship from the NIGMS (5T32 GM07365). R.W.B. was supported by a predoctoral NSF fellowship. D.L.D. was supported by a postdoctoral Muscular Dystrophy Association fellowship.

Correspondence should be addressed to Thomas L. Schwarz, Department of Molecular and Cellular Physiology, Beckman Center $111 \mathrm{~A}$, Stanford University Medical Center, Stanford, CA 94305-5426.

Copyright (C) 1993 Society for Neuroscience $0270-6474 / 93 / 134924-12 \$ 05.00 / 0$
}

Neurotransmitter release is mediated by the fusion of synaptic vesicles with the nerve terminal membrane. Synaptic vesicles must be synthesized and transported down the axon; they must also be loaded with transmitter and docked at the presynaptic membrane before they fuse with that membrane in response to elevated $\mathrm{Ca}^{2+}$ and release their contents into the synaptic cleft. Subsequently, they reform in the nerve terminal (Sudhof and Jahn, 1991; Trimble et al., 1991). While the molecular mechanisms underlying these processes are not understood, proteins associated with synaptic vesicles are probably involved at each step.

In recent years a great deal of progress has been made in identifying proteins in the synaptic vesicle membrane. The genes have been cloned and the primary structures determined for several of these proteins, including synaptophysin (Buckley et al., 1987; Lcube et al., 1987; Sudhof et al., 1987), SV2 (Bajjalieh et al., 1992; Feany et al., 1992), synaptotagmin/p65 (Perin et al., 1990; Wendland et al., 1991), vamp/synaptobrevin (Trimble et al., 1988; Elferink et al., 1989), rab3 (Touchot et al., 1987; Matsui et al., 1988), and synapsin (McCaffery and DeGennaro, 1986; Schiebler et al., 1986). Although biochemical and structural data have given some clues, the role these proteins play in the life of the vesicle is unknown. Three of these proteins are investigated here.

Synaptotagmin is an integral membrane protein with a short intravesicular tail, a single transmembrane domain, and two cytoplasmic repeats with homology to the $\mathrm{C} 2$ regulatory domain of protein kinase C (Perin et al., 1990). Biochemical data implicate synaptotagmin in vesicle docking via its association with syntaxin and $\mathrm{N}$-type $\mathrm{Ca}^{2+}$ channels (Bennett et al., 1992), with the latrotoxin receptor (Petrenko et al., 1991), and with RACKS, receptors for activated C-kinasc (Mochly-Rosen et al., 1992). In addition, synaptotagmin may respond to changes in $\mathrm{Ca}^{2+}$; the protein has been demonstrated to have both $\mathrm{Ca}^{2+}-$ and lipidbinding capabilities (Perin et al., 1990; Brose et al., 1992). Antibody and $\mathrm{C} 2$ domain peptide injections implicate synaptotagmin in vesicle release from PC12 cells (Elferink et al., 1993). However, it has been reported that $\mathrm{Ca}^{2+}$-stimulated release of dense-core vesicles from PC12 cells appears normal in a mutant cell line that does not express the protein (Shoji-Kasai et al., 1992).

Rab3 is a low-molecular-weight GTP-binding protein. It is believed to exist in a vesicle-associated form as well as a free cytosolic form and has been reported to move between these forms when synaptosomes are stimulated (Fischer von Mollard et al., 1991). Evidence from other small GTP-binding proteins in systems such as the Golgi apparatus suggests that these forms 
may correspond to GTP- and GDP-bound forms of the molecule. These changes in the form of the protein cause activation of the molecule and are then responsible for vesicles budding from or fusing with donor or acceptor membranes (Bourne, 1988; Mellman and Simons, 1992). Rab3 may mediate similar membrane trafficking and targeting events for synaptic vesicles.

Vamp is a small protein of 115-120 amino acids with a proline-rich amino terminus, a highly conscrved central domain, and a single transmembrane segment (Trimble et al., 1988). The function of vamp is unknown and it does not show homology to other protein families. The ability of tetanus toxin, an inhibitor of transmitter secretion, to proteolyze vamp suggests that vamp is essential for secretion (Schiavo et al., 1992a,b). A homolog was recently discovered in yeast (Gerst et al., 1992); thus, there may be a general cellular function for vamp in addition to the function served by its association with the synaptic vesicles. Vamp has also been observed in microvesicles in rat adipocytes, where it may be involved in the insulin-stimulated translocation of glucose transporters to the plasma membrane (Corley et al., 1992).

Drosophila homologs of synaptotagmin, rab3, and vamp (synaptobrevin) have been reported (Sudhof et al., 1989; Johnston et al., 1991; Perin et al., 1991). The gene of one of these, however, the synaptobrevin $(s y b)$ gene, is wcakly cxpressed in the nervous system: $s y b$ appears to be expressed at a low level ubiquitously and most abundantly in the gut (Chin et al., 1993). The presence of vamp proteins in all vertebrate synaptic vesicles suggested that Drosophila is also likely to express a neuronal vamp. This article reports the cloning of a new Drosophila vamp gene. This gene is more likely to encode the synaptic vesicleassociated isoform than is the previously reported $s y b$ gene and so we are calling it neuronal-synaptobrevin $(n-s y b)$. Northern analysis and in situ hybridization indicate that expression of this gene and the genes synaptotagmin $(s y t)$ and drab3 are localized to the nervous system. Furthermore, antibodies to synaptotagmin and vamp bind in synaptic regions of Drosophila, suggesting that the molecules are components of synaptic vesicles in the fly. These antibodies will also provide useful markers for the development of synapses and for analyzing mutations in these genes.

The physiology of synaptic transmission is very similar in Drosophila and vertebrates (Jan and Jan, 1976). As such, the molecular components of the release machinery are likely to be conserved. Previous reports have argued that the structural conservation of vamp/synaptobrevin, synaptotagmin, and rab3 homologs in Drosophila suggests that these proteins play a crucial role in synaptic vesicle physiology (Sudhof et al., 1989; Johnston et al., 1991; Perin et al., 1991). The finding that the Drosophila vamp homolog $s y b$ is a predominately non-neuronal gene demonstrates that this is not a sufficient criteria for assessing a protein's function (Chin et al., 1993). The localization of the novel vamp homolog $n-s y b$, as well as synaptotagmin and $d r a b 3$, to the nervous system, and the identification of synaptic synaptobrevin and synaptotagmin protein in Drosophila indicate that these proteins may function as synaptic vesicle proteins in an invertebrate. We intend to use Drosophila as a model system for understanding the functions of synaptic vesicle proteins. For this to succeed, the structural homologs in Drosophila of vertebrate synaptic vesicle proteins must also be functionally conserved. We find that $n-s y b$, synaptotagmin, and drab3 are strong candidates for genetic analysis. The evolutionary conservation of both structure and localization suggests that these three proteins have an important function in the life cycle of the synaptic vesicle.

\section{Materials and Methods}

Cloning of $\mathrm{n}$-syb. An amplified $\lambda$-Zap cDNA library that had been made to randomly primed Drosophila head mRNA was screened at low stringency using the open reading frame (ORF) of rat vampl cDNA (Elferink et al., 1989) as a probe. Approximately 750,000 plaques were screened. Three clones that also hybridized to Drosophila synaptobrevin $(s y b)$ were isolated and shown by restriction mapping and partial sequencing to be independent isolates of a single gene $(n-s y b)$. Hybridization conditions for low-stringency screening and Southern blotting were $6 \times$ SSC $(1 \times$ SSC: $0.15 \mathrm{~m} \mathrm{NaCl}, 0.015 \mathrm{~m} \mathrm{Na}$-citrate), $5 \times$ Denhardt's (Sambrook et al., 1989), 0.5\% SDS, and $200 \mu \mathrm{g} / \mathrm{ml}$ salmon sperm DNA at $55^{\circ} \mathrm{C}$. The stringency of the final washes was $2 \times \mathrm{SSC}, 0.1 \% \mathrm{SDS}$ at $55^{\circ} \mathrm{C}$. One of the three isolates (clone $8-1-2$ ) was sequenced on both strands using the dideoxynucleotide method (Sanger et al., 1977) and Sequenase enzyme (U.S. Biochemical) and both dGTP and dITP nucleotide mixes. The clone contained the entire open reading frame and about 1 kilobase $(\mathrm{kb})$ of $3^{\prime}$ untranslated sequence. This clone was used to rescreen the library at high stringency. A total of 900,000 plaques were screcned using the same hybridization buffer at $65^{\circ} \mathrm{C}$ and a final wash stringency of $65^{\circ} \mathrm{C}, 0.1 \times \mathrm{SSC}, 0.1 \% \mathrm{SDS} ; 900$ positive colonies were identified. Of 20 clones analyzed, all were shown to be from the $n$-syb gene by restriction mapping. This was further confirmed by partial sequencing of 12 clones. A second clone from this later screen was then sequenced through the entire open reading frame on one strand using the same procedures as above in order to confirm the sequence. Sequence analysis was done with the GAP and BESTFIT programs.

At least two forms of $n$-syb cDNA were observed. Of 14 clones sequenced through the translation start site (with a primer complimentary to nucleotides 262-277), 12 were identical to Figure 1. However, two clones had a different $5^{\prime}$ end; they join the other clones at the site of an intron at nucleotide 4 of the sequence in Figure 1, that is, immediately after the ATG that forms the start codon. The alternatively spliced end containcd stop codons in all frames, but no other in-frame start codons. It is possible that this transcript initiates translation at the second methionine, amino acid 56, but because the resulting protein would lack the proline head and some of the highly conserved central domain, it seems more likely that it represents a splicing intermediate that is not translated in vivo. The presence of such incompletely spliced transcripts is common in Drosophila libraries (Schwarz et al., 1990). Sequencing of the genomic clone revealed an insertion of six nucleotides at position 510. This insertion does not alter the reading frame and would encode an $A$ and $G$ in the amino acid sequence after G170. This addition may represent strain differences since the genomic library is Canton-S DNA while the cDNA library is Oregon-R DNA.

Cloning of synaptotagmin and drab3. An amplified Drosophila head cDNA library was screened at low stringency using the open reading frame of Discopyge ommata p65-A (Wcndland ct al., 1991) as a probc. Approximately 300,000 plaques were screened and 13 were isolated and shown to encode synaptotagmin by sequencing and restriction mapping. Hybridization and wash conditions were as described above for lowstringency screening. While all clones were derived from the same gene, two clones were found with alternate $5^{\prime}$ ends. One clone diverged between amino acids 59 and 60 , while the other diverged between the second and third bases of the codon for amino acid 61. Repeated attempts to find independent isolates with these alternate $5^{\prime}$ ends were unsuccessful. These clones may represent other, less abundant splice variants encoding alternate amino termini, but their rarity may indicate that they are splicing intermediates. To search for members of a synaptotagmin gene family, the Drosophila synaptotagmin clone was used to probe the library at very low stringency. Hybridization was as above except the temperature was $37^{\circ} \mathrm{C}$. The library filters werc washed, allowed to expose, and rewashed through a series of four graded increases in stringency. The first wash conditions were $6 \times$ SSC, $0.1 \%$ SDS at $37^{\circ} \mathrm{C}$; the second, $2 \times \mathrm{SSC}, 0.1 \%$ SDS at $37^{\circ} \mathrm{C}$; the third, $2 \times \mathrm{SSC}, 0.1 \%$ SDS at $48^{\circ} \mathrm{C}$; and the last, $2 \times \mathrm{SSC}, 0.1 \%$ SDS at $65^{\circ} \mathrm{C}$. Forty-eight positive colonies were identified and shown by sequencing or polymerase chain reaction (PCR) to be isolates from the same synaptotagmin gene. A low-stringency screen was also performed with $D$. ommata p65-C and no hybridizing clones were identified. Probes to $d r a b 3$ were obtained by PCR amplification of the gene from an adult head library using oligonucleotide primers based on the published sequence (John- 


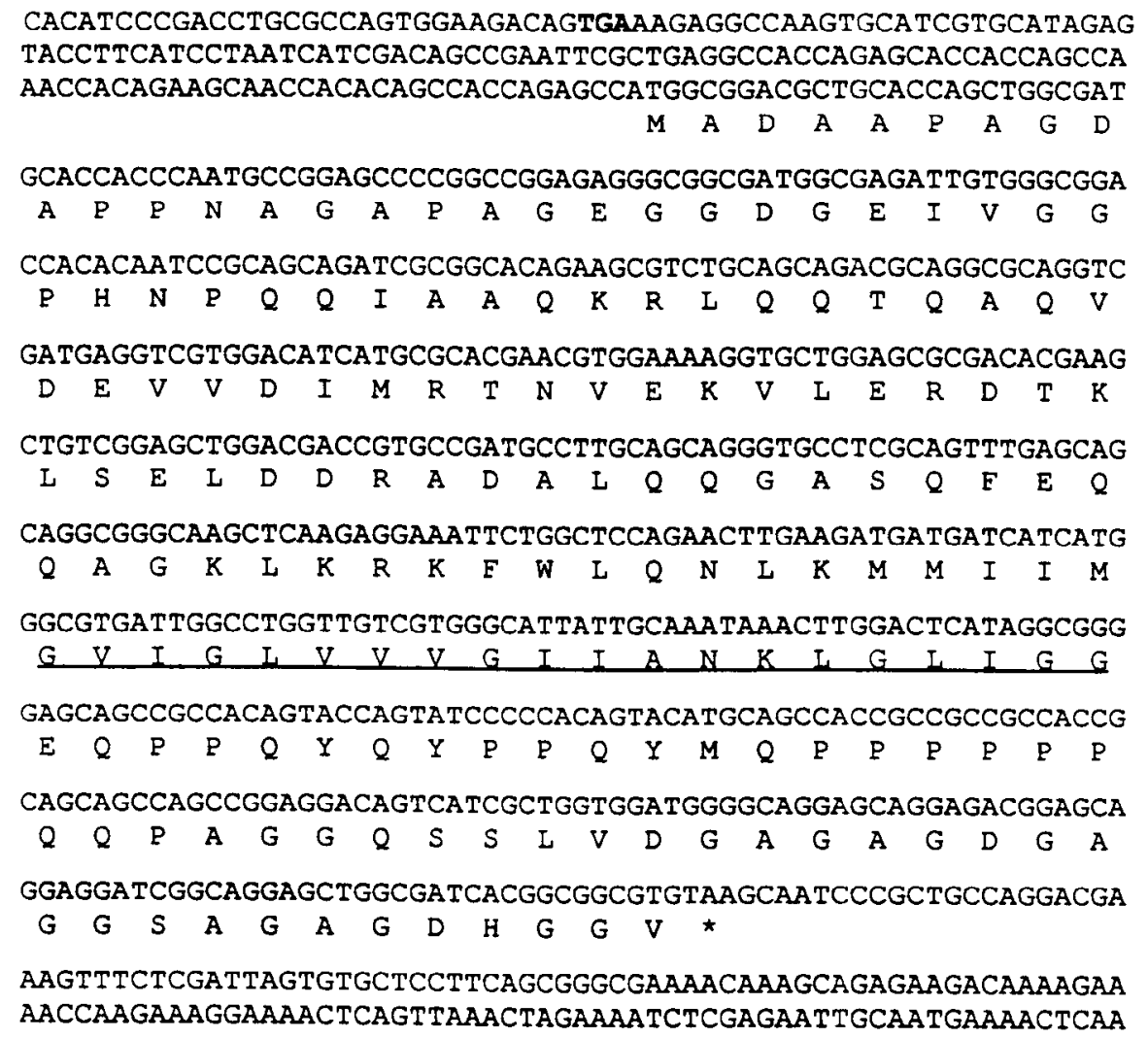

latcd amino The nucleotide and transgene. The boldfaced nucleotides -119 through -121 indicate an upstream stop codon preceding the start methionine. The transmembrane segment of the protein is indicated by underlining in the amino acid sequence. The total length of the protein is 181 aminoacids. ston et al. 1991). The PCR product was sequenced and shown to be identical to the published sequence in the open reading frame.

In situ hybridization to Drosophila polytene chromosomes. The salivary glands of third instar larvae were dissected out in Drosophila Ringer's solution, squashed onto slides, and fixed (Ashburner, 1989). The chromosomes were hybridized with biotin-labeled DNA probes (see below) in a $50 \%$ formamide buffer. After washing at $50^{\circ} \mathrm{C}$ in $2 \times \mathrm{SSC}$, the slides were treated with an HRP-avidin complex (DeTek kit, Enzo Diagnostics) and the signal developed using diaminobenzidine as a substrate for HRP. The chromosomes are counterstained with Geimsa at 1:20 in 0.1 M Na-phosphate, pH 6.9, and mounted in Permount (Fisher).

Isolation of genomic clones for drab3, synaptotagmin, and n-syb. A cosmid genomic library (Tamkun et al., 1992) was screened at high stringency (final wash conditions of $0.1 \times \mathrm{SSC}, 0.1 \% \mathrm{SDS}$ at $65^{\circ} \mathrm{C}$ ) with probes encoding the open reading frame of ejther Drosophila synaptotagmin or drab3. Fourteen clones were isolated for synaptotagmin and were shown to be overlapping by restriction mapping and Southern analysis. One clone was isolated for $d r a b 3$. It was shown to encode $d r a b 3$ by sequencing. A genomic clone for $n-s y b$ was found during a lowstringency screen of a $\lambda$-Charon 4A library (Maniatis et al., 1978) with the $s y b$ gene. Five to six genome equivalents were represented by the approximately 200,000 plaques screened. Final wash conditions were $1 \times \mathrm{SSC}$ at $50^{\circ} \mathrm{C}$. Fourteen hybridizing clones were isolated and analyzed. Seven were strongly positive and represented reisolates of $s y b$. All of the seven remaining clones were shown to be $n-s y b$ by restriction mapping, by high-stringency Southern blotting with $n$-syb cDNAs, and by sequencing.

Northern analysis of gene expression. PolyA-selected mRNA was isolated from staged Drosophila embryos, first, second, and third instar larvae, pupae, adult heads, and adult bodies by phenol/urea extractions (Schwarz et al., 1988). Approximately $5 \mu \mathrm{g}$ of mRNA per lane was separated in a $6.7 \%$ formaldehyde, $0.8 \%$ agarose gel (Sambrook et al., 1989). The mRNA was then transferred to Gene Screen 2 (DuPont), UV cross-linked, and hybridized at $50^{\circ} \mathrm{C}$ in $50 \%$ formamide, $6 \times \mathrm{SSC}$, $5 \times$ Denhardt's, $250 \mu \mathrm{g} / \mathrm{ml}$ salmon sperm DNA, and 5\% SDS. The stringency of the final wash was $65^{\circ} \mathrm{C}$, in $0.1 \times$ SSC, $0.1 \%$ SDS. The amount of mRNA loaded in each lane was quantified by probing each blot with rp49 (Aguade, 1988). Total KNA was isolated from timed embryo collections and each larval instar stage. The total RNA was then loaded at $20 \mu \mathrm{g}$ per lane and blotted as above for the $n$-syb developmental Northern. Blots were washed and hybridized at high stringency. The total RNA blot shown in this article was exposed for $4 \mathrm{~d}$ with one intensifying screen.

In situ hybridization to Drosophila whole-mount embryos and frozen sections. Whole-mount embryos were fixed according to the protocol of Tautz and Pfeifle (1989) with slight modifications. Adult frozen sections were cut, fixed, and pretreated according to the protocol of Hafen and Levine (1986). For both whole-mounts and sections, formaldehyde was used in place of paraformaldehyde and proteinase- $\mathrm{K}$ was used for $6 \mathrm{~min}$ at $50 \mu \mathrm{g} / \mathrm{ml}$ in place of pronase. Probes were made from DNA templates and were labeled with digoxygenin (see below). All hybridizations were done at $42-45^{\circ} \mathrm{C}$ in $50 \%$ formamide, $5 \times$ SSC, $100 \mu \mathrm{g} / \mathrm{ml}$ salmon sperm DNA, $50 \mu \mathrm{g} / \mathrm{ml}$ heparin, and $0.1 \%$ Tween- 20 . The signal was developed using alkaline phosphatase-conjugated anti-digoxygenin antibodies and X-phosphate and NBT (Boehringer Mannheim) according to the manufacturer's protocol; reactions were stopped in PBS, 10 mм EDT A, $0.5 \%$ glutaraldehyde for $d r a b 3$ and $s y t$. Specimens were then mounted in $80 \%$ glycerol.

DNA probe labeling. All library screening and Northern analysis were done using ${ }^{32} \mathrm{P}$-labeled DNA probes. These probes were prepared by standard random priming procedures using $\alpha^{32} \mathrm{P}-\mathrm{dCTP}$ as the labeling nucleotide. Biotin-labeled probes were synthesized by nick translation using Bio-16-dUTP (Enzo Diagnostics) as the labeled nucleotide. Digoxygenin-labeled probes were synthesized by random priming using the reagents supplied in the Genius Kit (Boehringer Mannheim). The manufacturer's protocol was followed with the addition of an extra 30 $\mu \mathrm{g}$ of random hexamers (Pharmacia) per reaction. Probes were resuspended in Tris-EDTA buffer containing $0.2 \%$ SDS.

Immunocytochemistry of adult sections. Frozen sections of $10-12 \mu \mathrm{m}$ thickness were cut and adhered to glass slides. Sections were fixed and stained according to a published protocol (Schwarz et al., 1990). The synaptotagmin primary antibody was provided by $\mathrm{K}$. Miller and B. Wendland (Stanford Univ. Medical Center) and is an affinity-purified rabbit polyclonal raised to the cytoplasmic domain of rat synaptotag$\mathrm{min}$. This antibody recognizes a single band of the correct size on immunoblots of Drosophila lysates. It was used at a dilution of 1:5000. Preincubation of the serum with the fusion protein immunogen blocked synaptotagmin staining. The $\mathrm{Cl} 10.1$ monoclonal anti-synaptobrevin 


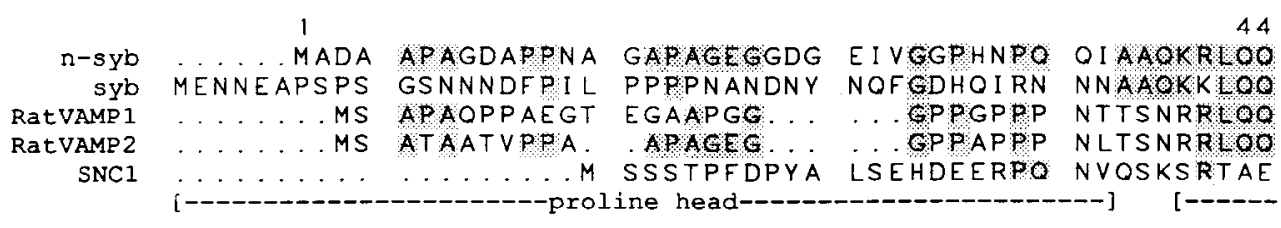

45

\begin{tabular}{|c|c|c|c|c|c|}
\hline$n-s y b$ & TOAOYOEYYO & ULTT NVL $\vee \checkmark L$ & ERDTKLSLID & 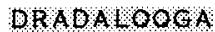 & $S O A+O A Q$ \\
\hline syb & TOSKK VDUVYG & INAVNYEKYL & ERDOKLSELG & ERADOLEOGA & SOFEOOAGA \\
\hline & TOAOVE BYYO & II RVNYDKVU & ERDOKUST & $D R A O A \cup O A G A$ & SVFESSAA \\
\hline VAMP 2 & TOAOYOLYY & 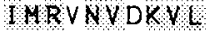 & ERNOK SOLO & $D R A O A Q O A G A$ & $\$ O+\%$ \\
\hline SNC1 & LOAE I DDT YG & IAKDNI NKVA & ERGERLTS I E & BKABN A V S A & QGFKRGAN \\
\hline
\end{tabular}

95

$n-s y b$
syb

RatVAMP

RatVAMP2

SNC1

$n-s y b$
syb

145

syb $\mathrm{PH}$
R*KFHLONLK MMIMGVIGL YVYGIIANKL GLIGGEOPPO YOYPPOYMOP KRKOWWANMK MNILGVIAV VLLIIVLVSV WPSSSDSGSG GGNKAITOAP KRKYWWKNCK MMIMLGAICA I IVVVIVIYI FT....... KRKYWWKNLK MUILLGVICA IILIIIIVYF RKAMHYKDLK AKMCLALVII I LLVVIIVPI [--hydrophobic domain--]

ST.........

AVHFSR.

intravesicular tail

Figure 2. Homology comparison of $n-s y b$ to other vamp/synaptobrevin homologs. The novel Drosophila $n-s y b$ sequence is aligned for maximum homology with the previously reported Drosophila $s y b$, rat vamp 1 and vamp2, and the yeast homolog SNC.1. Shading indicates amino acids that are identical between the $n-s y b$ and the previously reported sequences. The proline-rich amino terminus, the conserved central domain, the transmembrane segment, and the intravesicular region are defined below the sequences.

antibody (Baumert et al., 1989) was used at a dilution of 1:1000. This antibody recognizes a band of the correct molecular weight for $n$-syb on immunoblots of Drosophila head lysates. One unidentified, crossreacting band of about $55 \mathrm{kDa}$ was also detected. Signals for immunocytochemistry were developed using the $A B C$ kit (Vector) according to the manufacturer's protocol. Sections were dehydrated in ethanol and xylene and mounted in Permount.

\section{Results}

\section{A neuronal vamp cDNA}

In a search for a neuronal homolog of vamp in Drosophila, three clones were purified from a Drosophila adult head cDNA library that was probed at low stringency with the ORF of rat vampl. One of these was sequenced and a conceptual translation indicates it is a novel vamp homolog with an ORF of 543 bases predicting a protein of 181 amino acids (Fig. 1). A second, higher-stringency screen using the sequenced clone revealed that the gene is very abundant in the library, occurring at a frequency of nearly 1 in 1000 plaques.

The novel vamp homolog, which we have called $n-s y b$, is highly homologous to previously cloned vamp proteins (Fig. 2). The structural features of the family are preserved in $n-s y b$; it has a proline-rich amino terminus, a highly conserved central cytoplasmic region, and a single transmembrane scgment. Through the central cytoplasmic region and transmembrane segment, $n$-syb is $70 \%$ identical to $s y b$ and $67 \%$ and $75 \%$ identical to rat vamps 1 and 2 , respectively. The proline-rich amino terminus of $n-s y b$ is more similar to the rat vamps than is the equivalent region of the previously reported $s y b$. $n-s y b$ has an exceptionally long intravesicular carboxyl tail and in this it resembles one of the splicing variants of $s y b(s y b-a)$. While $s y b$ has at least one splice variant with a truncated tail $(s y b-b$; Chin et al., 1993), no such isoform has been identified for $n-s y b$.

We also searched for additional homologs by a low-stringency screen of a genomic library. The existence of homologous genes may frequently be more easily detected in a genomic library, since every gene should be represented equally, regardless of the level of expression of the gene or its restriction to a particular tissue or developmental stage. The $s y b$ gene was used as a probe to screen the genomic library at low stringency. In addition to reisolating the $s y b$ gene, seven more weakly hybridizing clones were also analyzed. All seven of these clones contained the $n$-syb gene; no additional members of the family were encountered. A $1.7 \mathrm{~kb}$ cDNA containing the ORF hybridizes to a single $8 \mathrm{~kb}$ EcoRI genomic fragment (Fig. $3 A$ ). From sequencing of genomic DNA, we determined that the ORF of $n$-syb is encoded by five exons; introns were identified at nucleotide positions 4,153 , 312 , and 365 as per the numbering in Figure 1. Genomic clones can be transformed into flies and used to rescue mutants genetically. Rescue, along with locations of intron/exon boundaries, will facilitate the identification of mutants and the amplification and sequencing of genomic DNA from mutant strains to identify the site of the mutation.

In situ hybridization of $n-s y b$ to polytene chromosomes places the gene near the left end of chromosome 3 in the region of $62 \mathrm{~A}$; it is not clustered with $s y b$, which is found at $46 \mathrm{~F}$.

\section{cDNA and genomic clones for synaptotagmin and drab3}

A Drosophila adult head cDNA library was screened at low stringency using a probe corresponding to most of the ORF of D. ommata synaptotagmin-A. Thirteen hybridizing clones were isolated and shown to encode a single Drosophila homolog of synaptotagmin. A sequence for Drosophila synaptotagmin (syt) has recently been published (Perin et al., 1991) that is nearly identical to our sequence (data not shown). Only one difference in the predicted protein sequence was found: amino acids 168 and $169, \mathrm{~V}$ and $\mathrm{Q}$, in the published sequence are not present in the clones we isolated. The Drosophila adult head cDNA library was also screened at low stringency with a probe made to Drosophila synaptotagmin and to D. ommata p65-C to look for other members of a gene family; in vertebrate species $(D . o m$ mata and the rat), two or more isoforms of the protein have been observed (Geppert et al., 1991; Wendland et al., 1991). The synaptotagmin protein in Drosophila, however, appears to be the product of a single gene in Drosophila; we did not find any additional homologs in these screens.

To isolate genomic clones, a cosmid library (Tamkun et al., 
A

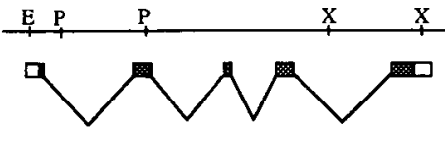

$x$ PE

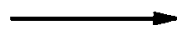

$1 \mathrm{~kb}$

B

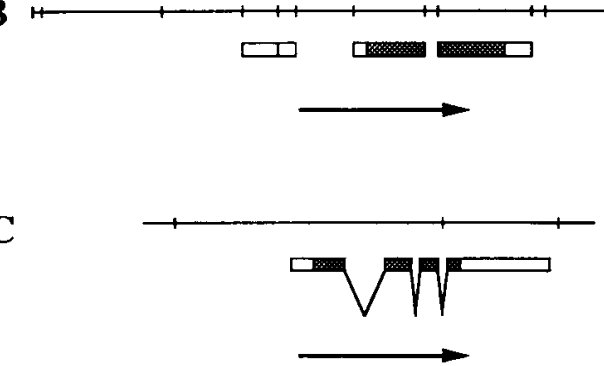

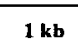

Figure 3. Partial genomic restriction maps for $n-s y b(A)$, syt $(B)$, and drab3 $(C) . A$, The entire $n$-syb ORF (shaded boxes) is located within $5.0 \mathrm{~kb}$ of genomic DNA, as is at least some $5^{\prime}$ and $3^{\prime}$ untranslated sequence (open boxes). Introns are present at nucleotide positions 4 , 153,312 , and 365 as per the numbering of the cDNA in Figure 1. Sizes of introns have not been determined. $B$, The $s y t$ cDNA is spread across at least $20 \mathrm{~kb}$ of genomic DNA. Those EcoRI restriction fragments that hybridize to a $2.2 \mathrm{~kb} s y t$ cDNA are indicated by the boxes. Oligonucleotide probes indicate that the two EcoRI fragments at the left include $5^{\prime}$ untranslated sequence and that the EcoRI fragment at the right includes both ORF and $3^{\prime}$ untranslated sequences. The entire ORF is present within two EcoRI fragments (shaded boxes). $C$. The entire drab3 ORF (indicated by the shaded boxes) is located within $4.3 \mathrm{~kb}$ of genomic DNA, as is at least some $5^{\prime}$ and $3^{\prime}$ untranslated sequence (open boxes). Three introns interrupt the ORF. These introns are approximately 400 , 100 , and 75 base pairs in length and occur at nucleotide positions 811 , 930 , and 1102 as per the numbering of Johnston et al. (1991). In $A$ the tick marks on the genomic map indicate $\operatorname{EcoRI}(E)$, PstI $(P)$, and XhoI $(X)$ restriction sites; in $B$ and $C$ they indicate EcoRI restriction sites. Arrows indicate the direction of transcription. A size marker is included for each panel.

1992) was screened with the ORF of Drosophila synaptotagmin and with a probe synthesized to the ORF of the previously cloncd Drosophila drab3. Fourteen overlapping synaptotagmin clones were isolated that contained either one or both of a 4.8 and a $6.5 \mathrm{~kb}$ EcoRI fragment that hybridized to an ORF probe. The 14 overlapping clones span more than $55 \mathrm{~kb}$ of genomic DNA. Probing Southern blots with a $2.2 \mathrm{~kb}$ cDNA that includes the entire ORF and with oligonucleotides to various regions of the synaptotagmin cDNA demonstrates that the cDNA is spread across at least $20 \mathrm{~kb}$ of genomic DNA. Genomic EcoRI fragments that hybridize to this CDNA are diagrammed in Figure $3 B$. All exons encoding the ORF are present in the 4.8 and 6.5 $\mathrm{kb}$ EcoRI fragments. For $d r a b 3$, a single hybridizing cosmid was isolated. It was shown to contain the $d r a b 3$ gene by sequencing. The entire ORF is represented in two genomic EcoRI fragments of 1.3 and $3.0 \mathrm{~kb}$. Subcloning, sequencing, and PCR between these fragments demonstrated that the $d r a b 3 \mathrm{ORF}$ is punctuated by three introns of approximately 400,100 , and 75 base pairs at nucleotide positions 811,930 , and 1102 as per the numbering of Johnston et al. (1991). An intron/exon map of that portion of the $d r a b 3$ gene that encodes the ORF is shown in Figure $3 C$.

\section{Transcription of synaptotagmin, drab3, and n-syb}

Since these Drosophila genes were found on the basis of homology to vertebrate proteins, and not by purification of pro-

teins from synaptic vesicles, we have sought evidence that they are indeed neuronal and synaptic by studying their expression pattern, first with RNA blots and then by in situ hybridization and immunocytochemistry (see below). In addition, because the predicted phenotype of a mutation in a gene expressed only at one developmental stage or only in a subset of neurons would differ from the phenotype predicted for a gene that functioned at all synapses, characterizing the distribution pattern is an important prerequisite for genetic studies. The expression of a gene product required at every synapse would be expected to begin at 8-15 hr of Drosophila development, a period of extensive neurite outgrowth and synapse formation. The first known requirement for synaptic function is in the emergence of the first instar larvae from the egg case ( $22 \mathrm{hr})$. In later larval periods, neuronal transcripts are often hard to see in RNA blots because the brain and nerve cord are so small in comparison to muscle and digestive organs at this stage. In the pupal stage, the dcvelopment of the adult nervous system requires the transcription of neuronal genes. In the adult, an approximately 10 -fold enrichment of neuronal transcripts can be observed when head RNA is compared to body RNA; although the body contains peripheral neurons and the thoracic ganglia they are again small in comparison to muscle and digestive tissues.

Northern analysis of the $n-s y b$ transcript demonstrates that it is present in mRNA isolated from embryos, larvae, pupae, and adults in a pattern much like that described above. $n$-syb has two transcripts of 3.0 and $3.2 \mathrm{~kb}$ (Fig. 4). The onset of embryonic expression appears to coincide with maturation of the nervous system at about $12 \mathrm{hr}$ of age, when synapses begin to form (Broadie et al., 1992). This contrasts with the homologous $s y b$ gene, which had been observed in very early embryos, prior to cellularization and neurogenesis (Chin et al., 1993). Prior to adulthood, the two $n-s y b$ transcripts appear to be present in roughly equal quantities. The adult fly expresses predominantly the $3.0 \mathrm{~kb}$ transcript, which is strongly enriched in the head (Fig. 4). When the same lanes were probed with $s y b$ (whose transcripts are 0.85 and $1.1 \mathrm{~kb}$ ), no significant enrichment in head versus body was evident.

Northern analysis of syt expression showed an onset of expression that similarly coincided with synaptogenesis and an enrichment in the head relative to the body. The message exists predominantly as 4.0 and $6.5 \mathrm{~kb}$ transcripts in both embryos and adults (Fig. 5). The abundant, lower-molecular-weight transcript in third instar larvae is not understood, although it is consistently observed with syt ORF probes. A longer exposure of this blot does indicate that second and third instar larvae also express the $4.0 \mathrm{~kb}$ transcript.

A $d r a b 3$ probe on the same mRNA blots hybridizes to a band of approximately $3.8 \mathrm{~kb}$ that is probably a doublet (Fig. 6). The developmental expression pattern of $d r a b 3$ is similar to that of $s y t$ and $n$-syb. The transcript first appears between 12 and 15 $\mathrm{hr}$ and is expressed throughout development, although a longer exposure is required to detect the larval signal. drab3 is also strongly enriched in the head compared to the body.

$\mathrm{n}$-syb, synaptotagmin, and $\mathrm{drab} 3 m R N A$ are localized to the nervous system

In situ hybridizations were performed to study further the expression patterns of each gene. We sought to determine if the gene was indeed expressed in neurons and to see if we could detect neuronal populations that did not express the gene. Such a gap in expression would imply either that the protein was not 
m

7.46-

$4.40-$

2.37-

$1.35-$

7.46---

4.40---

2.37---
Figure 4. Expression pattern of $n-s y b$ determined by Northern analysis. Detectable $n$-syb expression begins at 9$12 \mathrm{hr}$ of development, increases thereafter, and can be seen in all subsequent developmental stages. The transcript has two primary forms of 3.0 and $3.2 \mathrm{~kb}$; the relative abundance of these forms appears to be nearly equal throughout the embryonic and larval stages. The $3.0 \mathrm{~kb}$ transcript predominates in the pupae and adult and is highly enriched in the head compared to the body. The head and body lanes were also probed with the $s y b$ gene, which shows no comparable enrichment in the head. Lanes are denoted in hours of development for embryos; $L 1$, first instar larvae; $L 2$, second instar; $E L 3$, early third instar; $L L 3$, late third instar; $A D U L T$, whole adult; $B O D Y$, adult bodies; $H E A D$, adult heads. Lanes are loaded with 20 $\mu \mathrm{g}$ of total RNA, except the body and head lanes, which are loaded with $5 \mu \mathrm{g}$ of polyA ${ }^{+}$mRNA. The quantitation with rp49 is indicated. The signal near $2.0 \mathrm{~kb}$ is an artifact caused by the exclusion of degraded $n$-syb transcript by contaminating ribosomal RNA.

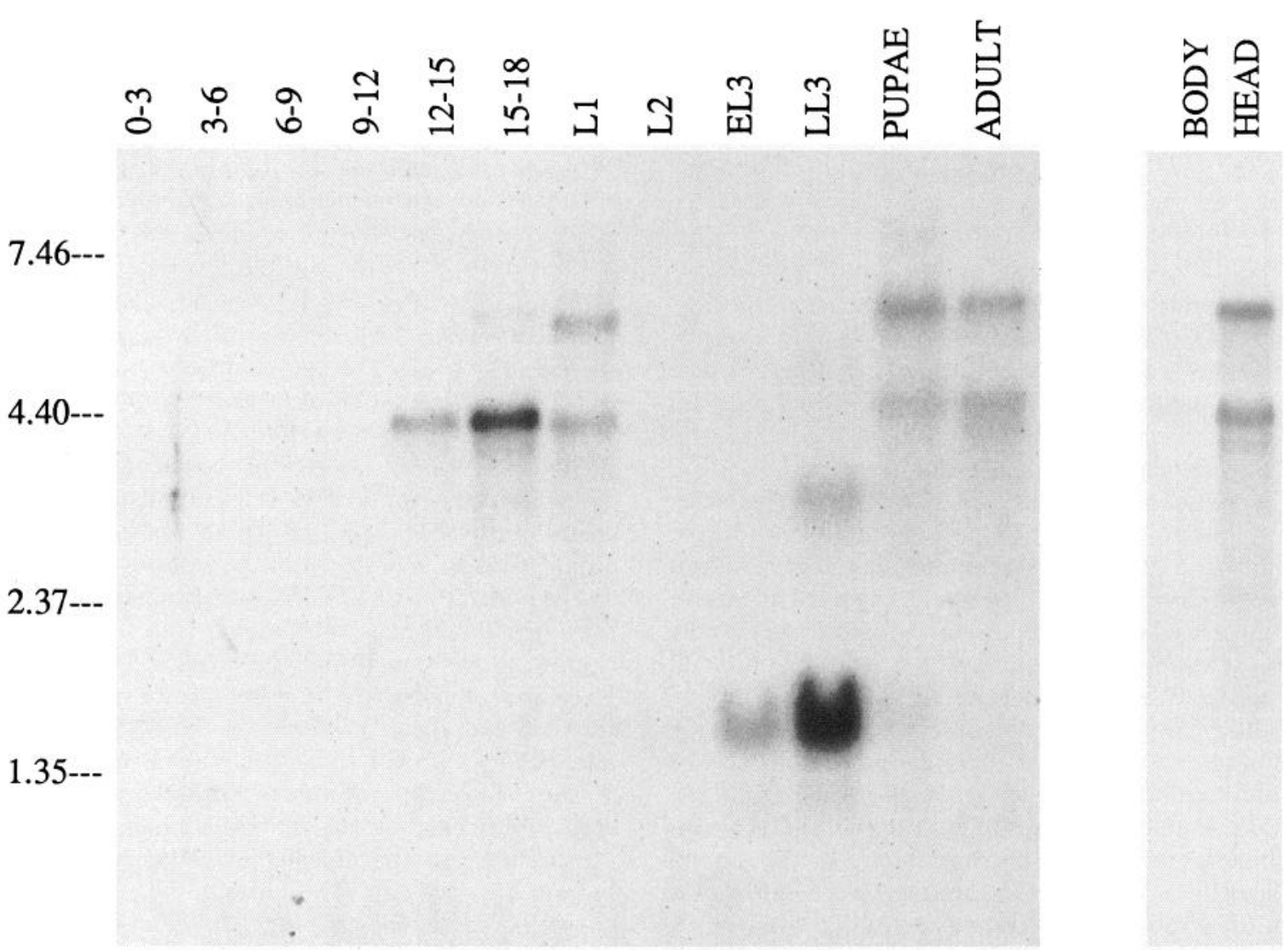

Figure 5. Expression pattern of syt determined by Northern analysis. Examination of the expression pattern of syt indicates that transcripts are present in all developmental stages and are highly enriched in the head. Transcription of syt begins between 9 and $12 \mathrm{hr}$ of development. The two predominant transcripts in the embryo and adult are 4.0 and $6.5 \mathrm{~kb}$. The faintness of the signal of the $4.0 \mathrm{~kb}$ transcript in second and third instar larvae (visible on longer exposures) probably reflects the extremely low percentage of larvae that is neuronal. The abundant, low-molecular-weight syt signal in the third instar larvae is not understood. Lanes are denoted in hours of development for embryos; other lanes are identified as in Figure 4. Lanes are loaded with $5 \mu \mathrm{g}$ of mRNA, except the head lane, which contains approximately five times less mRNA. 


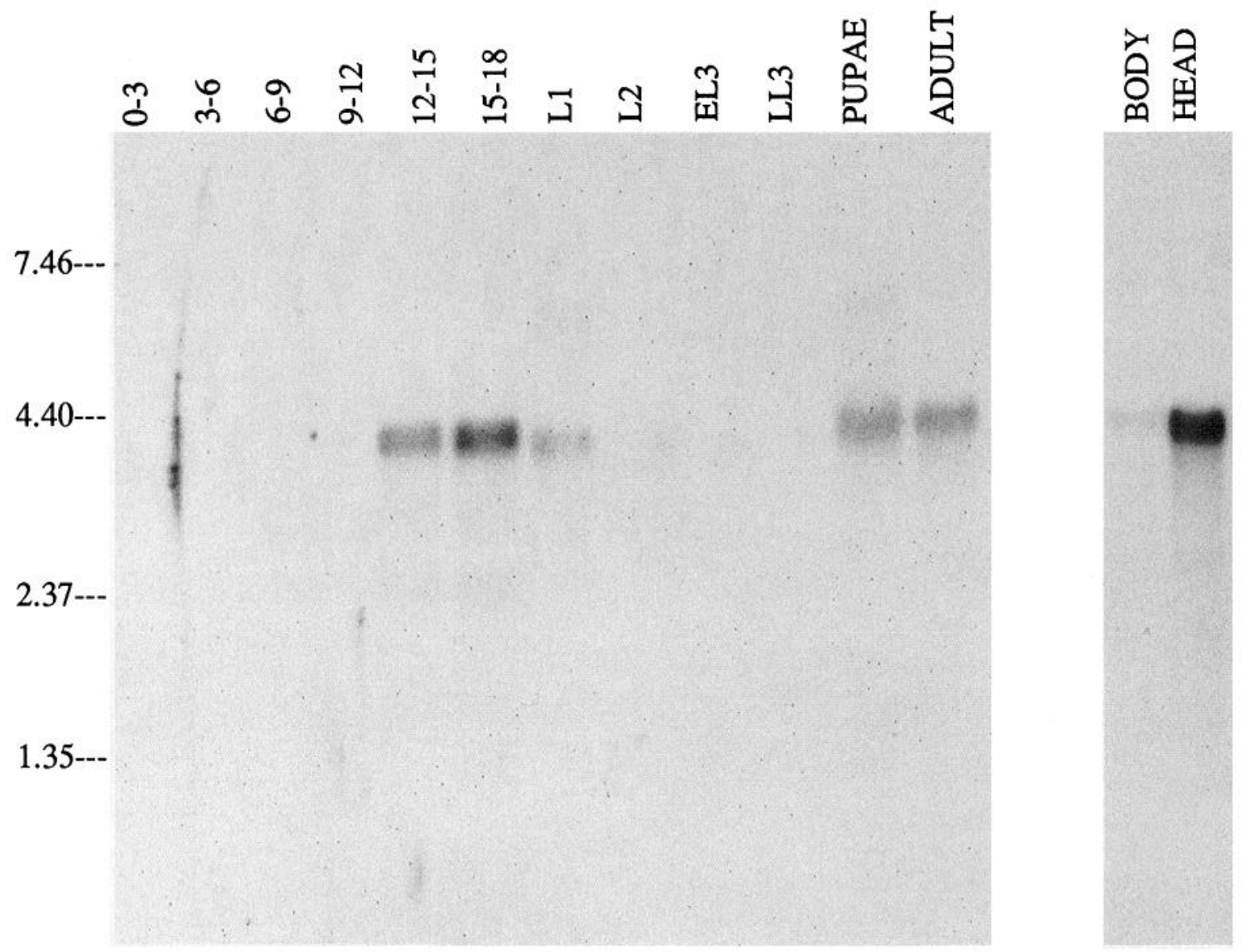

Figure 6. Expression pattern of drab3 determined by Northern analysis. drab3 is first expressed between 9 and 12 hr of development and is enriched in the head. The drab3 signal appears to be a doublet at $3.8 \mathrm{~kb}$. The barely detectable signal in second and third instar larvae probably reflects the extremely low percentage of larvae that is neuronal. Lanes are denoted in hours of development for embryos; other lanes are identified as in Figure 4. Lanes are loaded with $5 \mu \mathrm{g}$ of mRNA, except the head lane, which contains approximately five times less mRNA.

required for synaptic function or that other genes are present that encode isoforms of the protein. The resolution of these in situ hybridizations is not capable of determining if every single neuron contains the transcript, but they might reveal if a class of neurons such as photoreceptors or cells of the embryonic nerve cord was not expressing the genes.

$n$-syb, synaptotagmin, and drab3 distribution was studied in embryos and adults. The embryonic CNS consists roughly of two anterior ganglia, the sub- and supraesophageal ganglia, and the ventral nerve cord. The PNS is primarily involved in sensory function and consists of three, bilaterally symmetrical clusters of cells in most segments (Bodmer and Jan, 1987). Peripheral ganglia are also present at the anterior and posterior ends (the antennomaxillary complex and dorsal sensory cones). Sections through the head reveal the major features of the adult nervous system: photoreceptors and the optic ganglia that process the visual inputs are found at either side, and the central brain region and subesophageal ganglion lie in the middle. In the thorax, three large ganglia are present that are responsible for motor output to the flight muscles and legs and the reception of sensory information. As in other invertebrate nervous systems, the cell bodies of the central neurons form a cortical rind that surrounds the synaptic neuropil.

The expression pattern of $n$-syb was determined by in situ hybridization to whole-mount embryos (Fig. 7A-D) and adults (Fig. $7 G$ ). $n$-syb transcripts are first detectable at stage 13 or 14 , or about $11 \mathrm{hr}$ (Fig. $7 \mathrm{~B}$ ), in agreement with the results of the Northern analysis. The expression appears to be restricted to the nervous system, becoming quite robust in both the CNS and PNS by late embryogenesis (Fig. $7 C, D$ ). There were no apparent gaps of staining in the nervous system. Similarly, in situ hybridizations to frozen sections of adult flies indicate that the transcript is present in cell bodies of the visual system, central nuclei (Fig. $7 G$ ), and thoracic ganglia (not shown).

The expression of $d r a b 3$ in the embryo was examined by in situ hybridization of a cDNA probe to whole-mount embryos. Although the signals were weaker, the time course of drab3 expression was similar to that of $n$-syb, beginning at about stage 13 (data not shown). In later embryos, expression is robust in the CNS and apparent in parts of the PNS, such as the antennomaxillary complex (Fig. $7 E$ ), but was not detected in other sensory neurons. There were no apparent gaps of staining in the embryonic CNS. In sections of the adult brain (data not shown), the staining was detectable in the cell bodies of the central nuclei but was not apparent in the cortex of the visual system. Because of the generally weak staining, it is quite possible that $d r a b 3$ is expressed in the optic ganglia and embryonic sensory neurons. Antibodies are currently being generated to examine further the distribution of drab3.

The expression of synaptotagmin in the embryo was also examined in whole-mount embryos and was shown to develop with a time course similar to that of $n-s y b$ and drab3. Synap- 


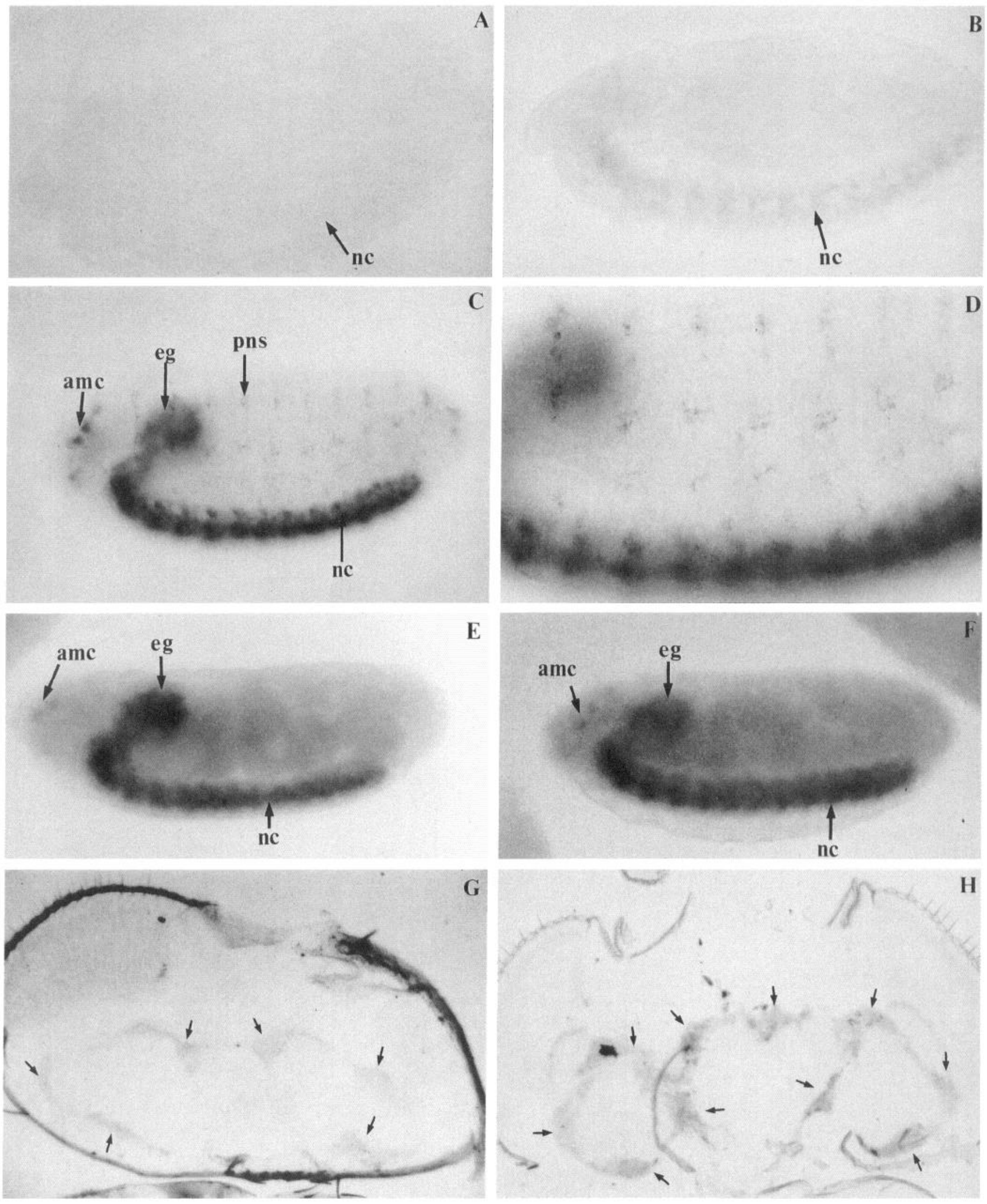

Figure 7. In situ hybridizations to localize transcripts in Drosophila whole-mount embryos and adult head sections with probes for $n$-syb, syt, and drab3. $n$-syb staining is shown in $A-D$ and $G$; syt staining, in $F$ and $H$; and drab3 staining, in $E$. $A$, No $n$-syb staining is detected in an early whole-mount embryo (stage 11-12). B. The earliest detectable $n$-syb expression is apparent in a stage $13-14$ embryo. $C$, A later embryo with a well-developed nervous system robustly expresses $n$-syb in both the CNS and PNS. $D$, A higher-magnification view of $C$ demonstrates that $n$-syb expression is present in most and perhaps all cells of the PNS. E, drab3 transcript is expressed throughout the embryonic CNS. Staining is also observed in the antennomaxillary complex of the PNS. $F$, syt transcript is present in the embryonic CNS and antennomaxillary complex. $G$ and $H$, Sections of adult heads indicate neuronal expression of $n-s y b(G)$ and $s y t(H)$ in the cell body layers of the adult CNS (arrows). amc, antennomaxillary complex; $e g$, esophageal ganglia; $n c$, nerve cord; $p n s$, peripheral nervous system. 


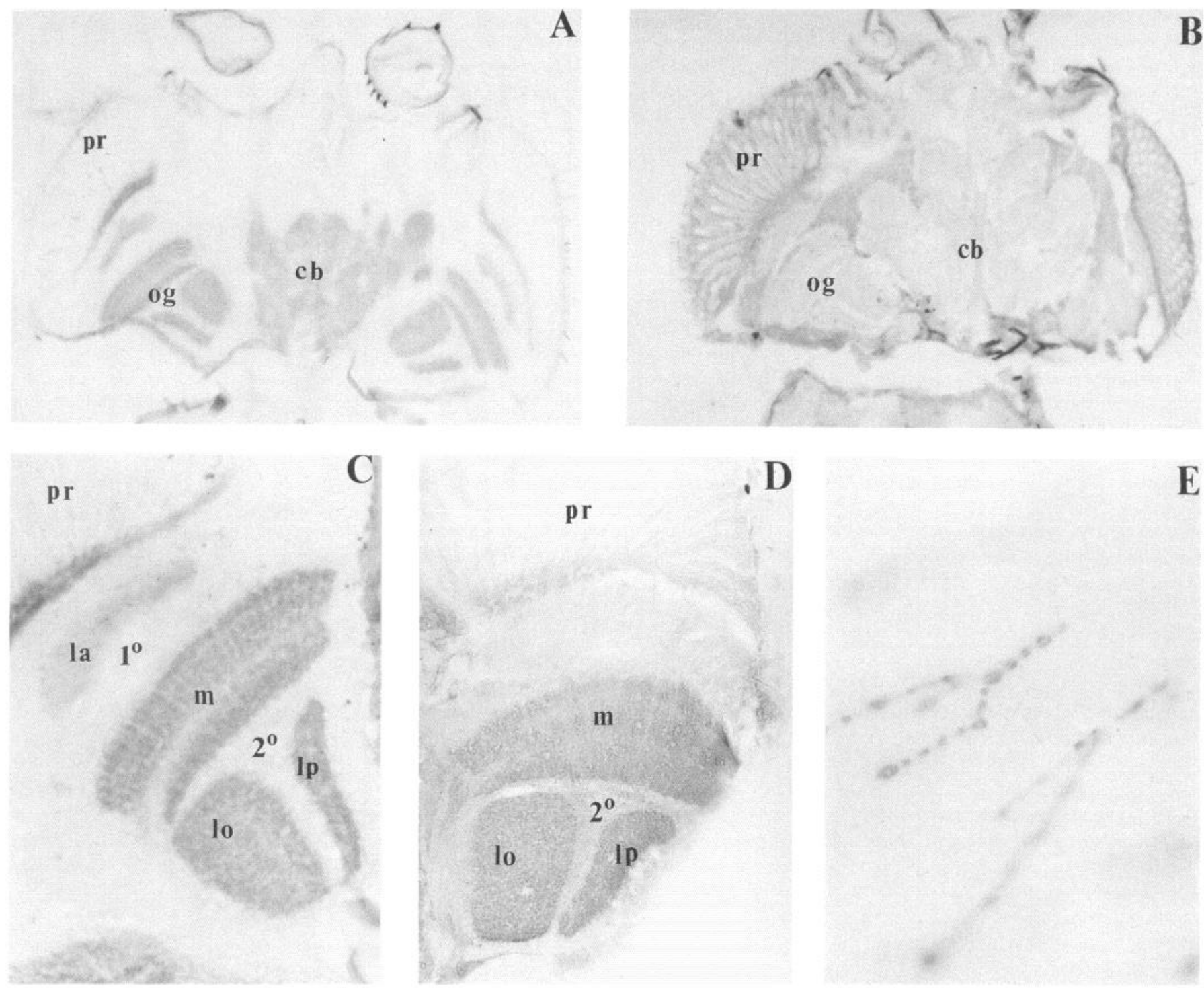

Figure 8. Immunocytochemistry of synaptotagmin and synaptobrevin. Staining with a polyclonal antibody to synaptotagmin is shown in $A-C$ and $E$. Staining with a monoclonal antibody to synaptobrevin is shown in $D$. $A$, A horizontal section of an adult fly shows synaptotagmin immunoreactivity in the synaptic regions of the visual system and CNS. $B$, This section was stained and reacted in parallel to that in $A$. The staining of the synaptic regions is blocked by preincubating the polyclonal synaptotagmin antiserum with its fusion protein antigen. Background staining of the cell bodies was consistently increased by the preincubation. $C$, A higher-magnification view of the staining in the synaptic areas of the adult visual system highlights the synaptic localization of synaptotagmin. Axon tracts in the primary and secondary optic chiasms are not labeled. $D$, Anti-synaptobrevin immunoreactivity in the adult visual system is also primarily synaptic. The lamina also shows synaptobrevin immunoreactivity, although it is not revealed in the section pictured here. The synaptic regions stained in $C$ and $D$ correspond to the cell bodies expressing $n$-syb and syt described in Figure 7, $G$ and $H$. E, Neuromuscular junctions on the body wall of whole-mount third instar larvae show synaptotagmin immunoreactivity. $c b$, central brain; $l a$, lamina; $l o$, lobula; $l p$, lobular plate; $m$, medulla; $o g$, optic ganglia; $p r$, photoreceptors; $1^{\circ}$, primary optic chiasm; $2^{\circ}$, secondary optic chiasm.

totagmin transcript was detected throughout the CNS (Fig. $7 F$ ) and PNS (data not shown), but not outside the nervous system. In frozen sections of adult flies, the transcript was present in the cell bodies of the CNS in both the brain (Fig. $7 \mathrm{H}$ ) and the thoracic ganglia (data not shown). The transcript appeared to be ubiquitous in the cell bodies of the CNS.

\section{Synaptotagmin and vamp proteins are present in synaptic areas of the brain}

By screening antibodies to the vertebrate vesicle proteins for staining in Drosophila, we could examine the distribution of the homologs more closely and determine if the proteins were concentrated in synaptic areas. Antibodies for both synaptotagmin and synaptobrevin identified epitopes in Drosophila (see Materials and Methods). No suitable antibody for drab3 is yet available.

Figure $8 A$ shows a frozen section of a Drosophila head stained with an antiserum raised against the cytoplasmic portion of rat synaptotagmin. The regions stained are the neuropil, and correspond to the synaptic connections and projections of the cell bodies that had been stained by in situ hybridization (Fig. $7 \mathrm{H}$ ). The specificity of the synaptotagmin staining in the neuropil was demonstrated by blocking the staining by preincubating the antiserum with the fusion protein antigen (Fig. $8 \mathrm{~B}$ ). Figure $8 \mathrm{C}$ is a higher-magnification view of the synaptotagmin staining in the visual system. The visual system consists of a series of 
integrating structures rich in synapses. The structures are the lamina, which contains most of the terminals of photoreceptor cells; the medulla, which is the next stage of visual processing; and the lobula and lobular plate, which relay the signal to the central brain and have been shown to be involved in motion detection (Buchner et al., 1984). These synapse-rich regions show significant synaptotagmin immunoreactivity, while the surrounding cell bodies do not. Several fiber tracts can be recognized in the visual system, particularly the primary and secondary optic chiasms. These axon-rich areas do not appear to contain synaptotagmin. Embryo fillets stained with synaptotagmin show a similar profile of staining in the neuropil (data not shown). In the third instar larva, the morphology of neuromuscular junctions has been characterized in detail with antibodies to neuronal surface antigens (Jan and Jan, 1982) and to glutamate (Johansen et al., 1989). We have stained for synaptotagmin in wholc-mounts of first, second, and third instar larvae in which the brain and body wall musculature were exposed and pinned back. The staining at the neuromuscular junction appears tightly confined to the nerve terminals (Fig. $8 E$ ). The axon of the motorneuron was not stained. CNS neuropil was also darkly labeled at this larval stage.

A monoclonal antibody, $\mathrm{Cl} 10.1$ (Baumert et al., 1989), raised to rat synaptobrevin was used to stain sections of adult Drosophila. This antibody recognizes a band of the correct molecular weight for $n-s y b$ on immunoblots, but also cross-reacts with one other high-molecular-weight band. Unfortunately, we cannot determine whether this cross-reactivity contributes to the cytochemical staining. Figure $8 D$ shows that the staining pattern in the adult visual system resembles that of synaptotagmin. Again, the synaptic regions show greater immunoreactivity than the cell bodies or axon tracts, although it may not be as highly localized as synaptotagmin. Staining was seen in other structures in the fly, including the thoracic ganglia and abdomen; no staining above background was evident in the muscles (data not shown). Staining of embryo fillets revealed signal in the CNS and other structures including the gut. It is likely that this antibody recognizes not only the $n-s y b$ protein, but also the $s y b$ protein and possibly additional undiscovered homologs. While it is impossible to be certain that the synaptic staining is due to the $n-s y b$ isoform, it is suggested by the in situ hybridization data, which showed that $n-s y b$, but not $s y b$, was abundant in the nervous system. Since no additional neuronal homologs were found, and since the staining by $\mathrm{Cl} 10.1$ in the nervous system was heaviest in neuropil, a synaptic localization for $n-s y b$ is indicated.

\section{Discussion}

We have undertaken an examination of Drosophila genes for synaptic vesicle proteins. With the cloning of the $n$-syb gene (Fig. 1), there are now three genes likely to encode synaptic vesicle proteins that have been identified in Drosophila: $n-s y b$, synaptotagmin, and drab3.

The distributions of these three Drosophila proteins were examined, in part, as a prelude to a genetic analysis of the function of these proteins. The importance of determining their distribution is twofold: it provides evidence that the sequence homology is reflecting a conserved function, and it guides future efforts to identify mutations by indicating whether a widespread synaptic defect ought to be sought, or a defect at a subset of synapses. The need for such analysis became evident when the distribution of the $s y b$ protein was found to be more widespread than expected, suggesting that an analysis of the function of $s y b$ may not be relevant to synaptic vesicle physiology. We have also addressed the question of genetic redundancy by looking for additional homologs of vamp, synaptotagmin and rab3. The genetic analysis of a protein's function is complicated if the products of several genes have the same function and thus mask the phenotype of mutations in any one gene. We therefore wanted to establish whether the genes we are studying are expressed in the nervous system, where in the nervous system they are expressed, whether they are localized to synapses, and if they are the predominant isoform present in the nervous system. The expression profile and tissue distribution of each of these three genes matched that expected of a synaptic vesicle protein that was used at most, and perhaps all, synapses.

\section{Multiple isoforms of the vamp/synaptobrevin family in Drosophila}

We have cloned and sequenced a new member of the vamp/ synaptobrevin family that we have called neuronal-synaptobrevin $(n-s y b)$ and mapped it to chromosome band $62 \mathrm{~A}$. We have demonstrated that vamp protein is present in Drosophila neuropil as would be expected if there were a synaptic vesicleassociated vamp. From a comparison of their expression patterns, $n-s y b$ is much more likely to encode this synaptic protein and to be involved in synaptic transmission than the previously identified $s y h$ gene (Chin et al., 1993). (1) $n-s y b$ expression is highly enriched in heads of flies, as would be expected for a neuronal product; $s y b$ is not (Fig. 4). (2) $n$-syb expression in embryos begins at about $12 \mathrm{hr}$, when synapses begin to appear (Figs. 4, 7B); $s y b$ is expressed prior to neurogenesis. (3) In situ hybridizations with $n-s y b$ probes identify transcripts specifically in neuronal tissues of embryos and adults (Fig. 7A-D,G); syb transcripts were below the level of detection in neuronal tissue but were abundant in regions of the gut and in malpighian tubules (Chin et al., 1993). Therefore, we propose that the $n$-syb gene is responsible for the production of synaptic vamp.

Staining with the monoclonal antibody $\mathrm{Cl} 10.1$ was strongest in the neuropil and in the abdomen of the fly. The non-neuronal staining is probably a product of the $s y b$ gene or of an unidentified third vamp homolog. Although there may be additional fly genes in the $s y b$ family, we have found no evidence for them. In a low-stringency screen of a genomic library, in which abundance and location of expression do not influence the likelihood of recovery, we repeatedly isolated $s y b$ and $n-s y b$ clones, but not any others. In the head cDNA library, where $n$ - $s y b$ was extremely abundant, no additional homolog was found. Thus, it is likely that any additional members are significantly less homologous to $s y b$ or to rat vamp than the two that are now known.

The presence of two vamp homologs in both the fly and the rat raises the question of whether there were two ancestral genes and whether each fly gene has a single rat equivalent. No strong relationship, however, can be discerned from comparison of their sequences. $n-s y b$ shows a slightly higher identity to rat vamp 2 than to rat vamp 1 , but $n-s y b$ is somewhat closer to both of the rat genes than is $s y b$. On a functional level, the presence of two homologs appears to serve different purposes in each species. While the two fly genes appear to have specialized for either a synaptic function or a general non-neuronal function, the two rat genes are both synaptic, though expressed in different subsets of neurons. Perhaps the nonsynaptic vamp-like proteins that have been observed on adipocyte vesicles will be a mam- 
malian counterpart to the $s y b$ gene (Corley et al., 1992). Since the non-neuronal distribution of $s y b$ suggests a more general role in membrane trafficking (Chin et al., 1993), we wondered if it was particularly close to $\mathrm{SNCl}$, a vamp homolog from yeast. However, $n-s y b$ and $s y b$ appear to be equidistant from the yeast SNCl. Overall similarity to SNCl is $60 \%$ for $n-s y b$ and $59 \%$ for $s y b$. Likewise, percentage identity to SNCl through the conserved domains is $31 \%$ for $n$-syb and $32 \%$ for $s y b$. Unlike syb, SNCl does not have a long intravesicular carboxyl tail and its amino terminus is shorter and much less rich in prolines than any other vamp homolog. It remains unclear what motifs, if any, are important for the specifically synaptic roles of neuronal vamps. We do not at present understand why the two fly genes have exceptionally large intravesicular tails.

\section{Does Drosophila contain another gene coding for a synaptotagmin protein or a rab3?}

In Drosophila, synaptotagmin immunoreactivity appears to be present throughout the neuropil. In both $D$. ommata and rat, synaptotagmin proteins are encoded by gene families whose members are differentially expressed in regions of the nervous system. In the fly, however, the transcript for synaptotagmin is present throughout development and could provide synaptotagmin protein at all stages. Although in a previous report (Perin et al., 1991) an embryonic transcript was not observed, we have found this transcript by looking in later-stage embryos, in which the nervous system has begun to develop. In addition, the transcript is widely distributed throughout the embryonic and adult CNS. Based on the resolution of the cytology we cannot claim that every single cell expressed a particular gene, but no gaps were seen in the in situ hybridizations or immunocytochemistry to suggest a particular population of nonexpressing cells. Furthermore, low-stringency screening of adult head libraries with D. ommata p65-A, p65-C, and Drosophila syt provided no evidence of another synaptotagmin gene. Therefore, we suggest that the identified synaptotagmin gene at 23B is the predominant, if not exclusive, source of synaptotagmin protein in Drosophila.

In vertebrates, there is a small family of rab3 genes. Because the small GTP-binding proteins share such extensive homology, it would be very difficult to design a low-stringency screen that selectively identifies rab3 genes. Instead, we have conducted a PCR screen using degenerate rab3-specific oligonucleotides. One additional rab3 gene was identified, but it does not seem to be abundantly expressed in the adult CNS (R. W. Burgess, unpublished observations). Since $d r a b 3$ is widely expressed throughout the Drosophila nervous system, we suggest that this gene is the major source of rab3 protein in the fly.

\section{The functions of n-syb, synaptotagmin, and $\mathrm{drab3}$ may be conserved from Drosophila to vertebrates}

In addition to identifying synaptic vesicle genes and addressing the question of possible genetic redundancy within gene families, we sought evidence that these proteins serve a similar function in Drosophila to what has been proposed in mammals, that is, a role in synaptic transmission. The structures of $n$-syb, synaptotagmin, and drab3 are all highly conserved between flies and vertebrates. These genes are $63 \%, 57 \%$, and $78 \%$ identical to their vertebrate homologs. Are they similarly localized as well? Because it has not been possible to purify intact synaptic vesicles from Drosophila tissue, we have examined the localization of $n-s y b$, synaptotagmin, and drab3 by in situ hybrid- ization and immunocytochemistry. As we have demonstrated here, these genes also show similar expression patterns to their vertebrate cousins. All three are greatly enriched in the nervous system, apparently throughout development. For n-syb and synaptotagmin, immunolocalization of the protein to the neuropil indicates that these proteins are synaptic. Unfortunately, no antibody is presently available for localizing drab3 in flies. This conservation of both structure and localization suggests that these three proteins act at steps in neurotransmission that have been conserved from invertebrates to vertebrates.

\section{A system for genetic analysis of vesicle proteins}

If the functions of $n$-syb, synaptotagmin, and drab3 are conserved in Drosophila, it should be possible to understand their function by a genetic analysis. Because each of the three genes appear to be expressed throughout the nervous system, a strong neurological phenotype would be expected for a fly deficient in one of the proteins. None of the three genes appears to be restricted to a small subset of neurons, such as the photoreceptors, which would have predicted a more limited behavioral defect, such as insensitivity to light. Nor were they restricted to a particular developmental stage, such as the adult, which would have predicted a late lethal period. The $n-s y b, s y t$, and $d r a b 3$ genes appear to encode the major neuronal forms of thesc protcins. If the proteins are essential for the function of the synapse, a deficient fly would be paralyzed and would probably die as a late-stage embryo, incapable of emerging from the egg case. A weak allele might have a more subtle neurological phenotype such as temperature-dependent paralysis, shaking, or decreased motor activity. The chromosomal location of all three genes is known: $n-s y b$ is at $62 \mathrm{~A}$, synaptotagmin is at $23 \mathrm{~B}$, and drab3 is at $47 \mathrm{~B}$. No neurological mutations have yet been mapped to any of these locations. We are therefore generating mutants in each of these genes. In the case of $s y t$, we have recently demonstrated that a null mutation of the gene described here is lethal. Synaptic transmission, however, persists in homozygous null first instar larvae, despite the absence of any detectable synaptotagmin protein (DiAntonio et al., 1993). Further analyses of the mutant phenotype of $s y t$, as well as $n-s y b$ and $d r a b 3$, may illuminate the function of these proteins in the process of neurotransmitter secretion.

\section{References}

Aguade M (1988) Nucleotide sequence comparison of the rp49 gene region between Drosophila subobscura and $D$. melanogaster. Mol Biol Evol 5:433-441.

Ashburner M (1989) Drosophila: a laboratory manual. Cold Spring Harbor, NY: Cold Spring Harbor Laboratory.

Bajjalieh SM, Peterson K, Shinghal R, Scheller RH (1992) SV2, a brain synaptic vesicle protein homologous to bacterial transporters. Science 257:1271-1273.

Baumert M, Maycox PR, Navone F, De Camilli P, Jahn R (1989) Synaptobrevin: an integral membrane protein of 18,000 daltons present in small synaptic vesicles of rat brain. EMBO J 8:379-384.

Bennett MK, Calakos N, Scheller RH (1992) Syntaxin: a synaptic protein implicated in docking of synaptic vesicles at presynaptic active zones. Science 257:255-259.

Bodmer R, Jan Y (1987) Morphological differentiation of the embryonic peripheral neurons in Drosophila. Rouxs Arch Dev Biol 196:6977.

Bourne HR (1988) Do GTPases direct membrane traffic in secretion? Cell 53:669-671.

Broadie K, Skaer H, Bate M (1992) Whole-embryo culture of Drosophila: development of embryonic tissues in vitro. Rouxs Arch Dev Biol 201:364-375.

Brose N, Petrenko AG, Sudhof TC, Jahn R (1992) Synaptotagmin: a 
calcium sensor on the synaptic vesicle surface. Science 256:10211025.

Buchner E, Buchner S, Bulthoff I (1984) Deoxyglucose mapping of nervous activity induced in Drosophila brain by visual movement. $J$ Comp Physiol [A] 155:471-483.

Buckley KM, Floor E, Kelly RB (1987) Cloning and sequence analysis of cDNA encoding p38, a major synaptic vesicle protcin. J Cell Biol 105:2447-2456.

Chin AC, Burgess RW, Wong BR, Schwarz TL, Scheller RH (1993) Differential expression of transcripts from $s y b$, a Drosophila vamp gene that is abundant in non-neuronal cells. Gene 131:173-180.

Corley CC, Trimble WS, Lienhard GE (1992) Members of the vamp family of synaptic vesicle proteins are components of glucose transporter-containing vesicles from rat adipocytes. J Biol Chem 267:1 $1681-$ 11684.

DiAntonio A, Parfitt KD, Schwarz TL (1993) Synaptic transmission persists in synaptotagmin mutants of Drosophila. Cell 73:1281-1290.

Elferink LA, Trimble WS, Scheller RH (1989) Two vesicle-associated membrane protein genes are differentially expressed in the rat central nervous system. J Biol Chem 264:11061-11064.

Elferink LA, Peterson MR, Scheller RH (1993) A rolc for synaptotagmin (p65) in regulated exocytosis. Cell 72:153-159.

Feany MB, Lee S, Edwards RH, Buckley KM (1992) The synaptic vesicle protein SV2 is a novel type of transmembrane transporter. Cell 70:861-867.

Fischer von Mollard G, Sudhof TC, Jahn R (1991) A small GTPbinding protein dissociates from synaptic vesicles during exocytosis. Nature 349:79-81.

Geppert M, Archer BT III, Sudhof TC (1991) Synaptotagmin II. J Biol Chem 266:13548-13552.

Gerst JE, Rodgers L, Riggs M, Wigler M (1992) SNC1, a yeast homolog of the synaptic vesicle-associated membrane protein/synaptobrevin gene family: genetic interactions with the RAS and CAP genes. Proc Natl Acad Sci USA 89:4338-4342.

I Jafen E, Levine M (1986) The localization of RNAs in Drosophila tissue sections by in situ hybridization. In: Drosophila: a practical approach (Roberts DB, ed), pp 139-158. Oxford: IRL.

Jan LY, Jan YN (1976) Properties of the larval neuromuscular junction in Drosophila melanogaster. J Physiol (Lond) 262:189-214.

Jan LY, Jan YN (1982) Antibodies to horseradish peroxidase as specific neuronal markers in Drosophila and in grasshopper embryos. Proc Natl Acad Sci USA 72:2700-2704.

Johansen J, Halpern ME, Johansen KM, Keshishian H (1989) Stereotypic morphology of glutamatergic synapses on identified muscle cells of Drosophila larvae. J Neurosci 9:710-725.

Johnston PA, Archer BT III, Robinson K, Mignery GA, Jahn R, Sudhof TC (1991) rab3a attachment to the synaptic vesicle membrane mediated by a conserved polyisoprenylated carboxy-terminal sequence. Neuron 7:101-109.

Leube RE, Kaiser P, Seiter A, Zimbelmann R, Franke WW, Rehm H, Knaus P, Prior P, Betz H, Reinke H, Beyreuther K, Wiedenmann B (1987) Synaptophysin: molecular organization and mRNA expression as determined from cloned cDNA. EMBO J 6:3261-3268.

Maniatis T, Hardison RC, Lacy E, Lauer J, O'Connell C, Quon D, Sim GK, Efstratiadis A (1978) The isolation of structural genes from libraries of eucaryotic DNA. Cell 15:687-701.

Matsui Y, Kikuchi A, Kondo J, Hishida T, Teranishi Y, Takai Y (1988) Nucleotide and deduced amino acid sequences of a GTP-binding protein family with molecular weights of 25,000 from bovine brain. J Biol Chem 263:11071-11074.

McCaffery CA, DeGennaro LJ (1986) Determination and analysis of the primary structure of the nerve terminal specific phosphoprotein, synapsin I. EMBO J 5:3167-3173.

Mellman I, Simons K (1992) The Golgi complex: in vitro veritas? Cell 68:829-840.

Mochly-Rosen D, Miller KG, Scheller RH, Khaner H, Lopez J, Smith BL (1992) p65 fragments, homologous to the $\mathrm{C} 2$ region of protein kinase $\mathrm{C}$, bind to the intracellular receptors for protein kinase $\mathrm{C}$. Biochemistry 31:8120-8124.

Perin MS, Fried VA, Mignery GA, Jahn R, Sudhof TC (1990) Phospholipid binding by a synaptic vesicle protein homologous to the regulatory region of protein kinase $C$. Nature 345:260-263.

Perin MS, Johnston PA, Ozcelik T, Jahn R, Franke U, Sudhof TC (1991) Structural and functional conservation of synaptotagmin (p65) in Drosophila and humans. J Biol Chem 266:615-622.

Petrenko AG, Perin MS, Davletov BA, Ushkaryov YA, Geppert M, Sudhof TC (1991) Binding of synaptotagmin to the $\alpha$-latrotoxin receptor implicates both in synaptic vesicle exocytosis. Nature 353: 65-68.

Sambrook J, Fritsch EF, Maniatis T (1989) Molecular cloning: a laboratory manual. Cold Spring Harbor, NY: Cold Spring Harbor Laboratory.

Sanger F, Nicklen S, Coulson AR (1977) DNA sequencing with chain terminating inhibitors. Proc Natl Acad Sci USA 74:5463-5467.

Schiavo G, Benfenati F, Poulain B, Rossetto O, Polverino de Laureto P, Das Guptal BR, Montecucco C (1992a) Tetanus and botulinum-B neurotoxins block neurotransmitter release by proteolytic cleavage of synaptobrevin. Naturc 359:832-835.

Schiavo G, Poulain B, Rossetto O, Benfenati F, Tauc L, Montecucco C (1992b) Tetanus toxin is a zinc protein and its inhibition of neurotransmitter release and protease activity depend on zinc. EMBO J 11:3577-3583.

Schiebler W, Jahn R, Doucet JP, Rothlein J, Greengard P (1986) Characterization of synapsin I binding to small synaptic vesicles. J Biol Chem 261:8383-8390.

Schwarz TL, Tempel BL, Papazian DM, Jan YN, Jan LY (1988) Multiple potassium-channel components are produced by alternative splicing at the Shaker locus in Drosophila. Nature 331:137-145.

Schwarz TL, Papazian DM, Caretto RC, Jan YN, Jan LY (1990) Immunological characterization of $\mathrm{K}^{+}$channel components from the Shaker locus and differential distribution of splicing variants in Drosophila. Neuron 2:119-127.

Shoji-Kasai Y, Yoshida A, Sato K, Hoshino T, Ogura A, Kondo S, Fujimoto Y, Kuwahara R, Kato R, Takahashi M (1992) Neurotransmitter release from synaptotagmin-deficient clonal variants of PC1 2 cells. Science 256:1820-1823.

Sudhof TC, Jahn R (1991) Proteins of synaptic vesicles involved in exocytosis and membrane recycling. Neuron 6:665-677.

Sudhof TC, Lottspeich F, Greengard P, Mehl E, Jahn R (1987) A synaptic vesicle protein with a novel cytoplasmic domain and four transmembrane regions. Science 238:1142-1144.

Sudhof TC, Baumert M, Perin M, Jahn R (1989) A synaptic vesicle membrane protein is conserved from mammals to Drosophila. Neuron 2:1475-1481.

Tamkun JW, Deuring R, Scott MP, Kissinger M, Pattatucci AM, Kaufman TC, Kennison JA (1992) brahma: a regulator of Drosophila homeotic genes structurally related to the yeast transcriptional activator SNF2/SWI2. Cell 68:561-572.

Tautz D, Pfeifle C (1989) A non-radioactive in situ hybridization method for the localization of specific RNAs in Drosophila embryos reveals translational control of the segmentation gene hunchback. Chromosoma 98:81-85.

Touchot N, Chardin P, Tavitian A (1987) Four additional members of the ras gene superfamily isolated by an oligonucleotide strategy; molecular cloning of YPT-related cDNAs from a rat brain library. Proc Natl Acad Sci USA 84:8210-8214.

Trimble WS, Cowan DM, Scheller RH (1988) vamp-1: a synaptic vesicle-associated integral membrane protein. Proc Natl Acad Sci USA 85:4538-4542.

Trimble WS, Linial M, Scheller RH (1991) Cellular and molecular biology of the presynaptic nerve terminal. Annu Rev Neurosci 14: 93-122.

Wendland B, Miller KG, Schilling J, Scheller RH (1991) Differential expression of the p65 gene family. Neuron 6:993-1007. 